\title{
Photocatalytic Degradation of E. coli and S. aureus by Multi Walled Carbon Nanotubes
}

\author{
Madhuri Sharon ${ }^{1, \uparrow}$, Suprama Datta ${ }^{2}$, Sejal Shah ${ }^{2}$, Mahesh war Sharon ${ }^{2}$, T. Soga ${ }^{3}$ and Rakesh Afre \\ ${ }^{1}$ MONAD Nanotech Pvt. Ltd., A-702 Bhawani Towers, Powai, Mumbai 400076, India \\ ${ }^{2}$ Nanotechnology Research Center, Birla College, Kalyan 421 304, Maharashtra, India \\ ${ }^{3}$ Graduate School of Engineering, Nagoya Institute of Technology, Gokiso-Cho, Shova-Ku, Nagoya 466, Japan \\ ^e-mail: sharonmadhuri@yahoo.com \\ (Received July 3, 2007; Accepted September 13, 2007)
}

\begin{abstract}
Carbon Nano Tubes could be either metallic or semi-conducting in nature, depending on their diameter. Its photocatalytic behavior has given an impetus to use it as an anti-microbial agent. More than 95\% Escherichia coli and Staphylococcus aureus bacteria got killed when exposed to Carbon Nano Tubes for 30 minutes in presence of sunlight. Carbon Nano Tubes are supposed to have smooth surface on to which it accumulates positive charges when exposed to light. The surface that is non illuminated has negative charge. At the cellular level microorganisms produce negative charges on the cell membrane, Therefore damaging effect of multi walled carbon nano tubes (exposed to light) on the microorganisms is possible. In this paper, photo catalytic killing of microbes by multi walled carbon nano tubes is reported. Killing was due to damage in the cell membrane, as seen in SEM micrographs. Moreover biochemical analysis of membrane as well as total cellular proteins by SDS PAGE showed that there was denaturation of membrane proteins as well as total proteins of both the microbes studied. The killed microbes that showed a decrease in number of protein bands (i.e. due to breaking down of proteins) also showed an increase in level of free amino acids in microbes. This further confirmed that proteins got denatured or broken down into shorter units of amino acids. Increased level of free amino acids was recorded in both the microbes treated with multi walled carbon nano tubes and sunlight.
\end{abstract}

Keywords : Photocatalysis, Multi walled Carbon nanotubes, Escherichia coli, Staphylococcus aureus

\section{Introduction}

Discovery of fullerenes provided exciting insights into carbon nanostructures. The specific architectures of Carbon Nano Materials (CNM) built from $\mathrm{sp}^{2}$ carbon units based on simple geometrical principles have been found to result in new symmetries and structures [1] that have fascinating and useful properties.

Nearly a decade after their discovery, biologists covet the uses of Carbon Nano Tubes (CNTs) for various applications, because of the scale and their unique and novel structural, mechanical, electronic, thermal and chemical properties.

Sharon et al., 2005 [2] have postulated that when a semiconductor (either CNT or iron oxide) is in contact with any other materials like solution of some inorganic salt or a buffer solution, a depletion region is formed like one forms a metal-Schottky junction at the interface of CNT and inorganic salt solution. When this depletion region is illuminated with light source of energy equivalent to the band gap of the material, the interface gets accumulated with photogenerated electrons and holes. These photogenerated carriers are highly reactive and when they come in contact with any organic material, the latter is completely decomposed by oxidation/ reduction process. Since all living organisms are made up of macromolecules like proteins, such photo catalytic action will also decompose the cell wall proteins leading to destruction of the cell wall [2]. Killing microbes is commonly achieved by certain chemical agents which often adds to the environmental pollution due to toxicity. Two inorganic approaches can be used for killing microbes either by the photocatalytic activity or by exploiting the toxicity of certain metallic cations such as silver [3, 4]. Photocatalytic killing of microbes by CNT has already been shown [2 and the references there in]. It was suggested by Sharon et al. that carbon nanomaterials of specific band gap (band gap1.2 eV) can possess the property of semi-conducting nature depending on its internal diameter (between $20-50 \mathrm{~nm}$ ), that may damage the cell membrane due to photocatalytic activity of CNT causing death of microbes.Though Sharon et al. [2] have postulated this hypothesis, in the present work we have tried to give an experimental proof for the photo catalytic degradation of membrane proteins which causes the death of microbes. 


\section{Experimental}

\subsection{Selection of Microbes}

Two microbes having different composition of cell membrane i.e. Escherichia coli NCIM 5051 (Gram negative coccobacilli) and Staphylococcus aureus NCIM 2079 (Gram positive cocci); procured from National Chemical Laboratories, Pune, India were selected for the present work.

Cultures were maintained on 'Sterile Nutrient Agar' at $\mathrm{pH}$ 7.2 for growth. Growth curve of microbial cultures were found out by following the increase in cell mass at regular time interval and by measuring turbidity at $520 \mathrm{~nm}$ with a spectrophotometer. Cultures in the mid log phase of growth were taken for the experiment.

During exposure of microbes to Multi Walled Carbon Nanotubes (MWCNT) and sunlight they were grown on 'Sterile Nutrient Broth'. MWCNT was procured from MONAD Nanotech Pvt. Ltd. India, having following specifications: Synthesized by: CVD process from camphor, 20-40 nm external diameter and 5-15 $\mu \mathrm{m}$ length, MWCNT content $95 \%$ having $40-300 \mathrm{~m}^{2} / \mathrm{g}$ specific surface area and $1812 \pm$ $300 \mathrm{~W} / \mathrm{m} \cdot \mathrm{K}$ thermal conductivity, $2 \%$ amorphous Carbon and $\leq 2 \%$ Ash. MWCNTs were further purified by acid $(\mathrm{HCl})$ treatment to remove the metal catalyst, amorphous carbon and ash present in the MWCNT sample.

\subsection{Treatment of Escherichia coli and Staphylococcus aureus with MWCNT and exposure to sunlight}

Loopful of $12 \mathrm{~h}$ old cultures (in mid log phase) of Escherichia coli and Staphylococcus aureus were taken in $100 \mathrm{ml}$ 'Sterile Nutrient Broth' having required concentrations $(0,10,100 \& 500 \mathrm{mg} / \mathrm{l})$ of MWCNT. Six replica of each treatment was prepared in flasks.

$25 \mathrm{ml}$ of culture from each of the above flasks were aseptically transferred on sterile petriplates and were exposed to dark and sunlight for $30 \mathrm{~min}$. The experiments were performed at 10 am when the intensity of sunlight was 20,000 lux.

Effect of MWCNT and sunlight was studied by recording the survival of microbes, scanning electron microscopy, membrane and total protein analysis by electrophoresis and total protein and free amino acid content by biochemical assay.

\subsection{Mortality of microbes treated with MWCNT and sun- light}

After exposure to the sunlight and MWCNT, viability of both the microbes were checked by spread plate method using Sterile Nutrient Agar. Each bacterium would thus result in production of one colony, which was counted to determine the number of surviving bacteria in the given suspension. Dense suspensions of cells were suitably diluted to avoid over-crowding of the colonies on the medium. A serial dilution from $10^{-1}$ to $10^{-5}$ using $4.5 \mathrm{ml}$ of sterile saline and $0.5 \mathrm{ml}$ of respective culture was prepared. Aliquot of 0.1 $\mathrm{ml}$ of respective dilution was spread on to the Sterile Nutrient Agar plate with the help of a glass spreader. Plates were inverted and incubated at $37^{\circ} \mathrm{C}$ for $24 \mathrm{~h}$. Number of colonies developed on the plate were counted to calculate the viability of the microbes. Thus the mortality due to treatment was assessed. Following assays of both the microbes were done, after they were exposed to MWCNT and sunlight.

\subsection{Membrane and total protein assay (by SDS-PAGE methods) of microbes treated with MWCNT and sunlight [5]}

\subsubsection{Extraction of membrane protein}

Treated and control cultures of E. coli and $S$. aureus were spun in the medium at $6000 \mathrm{rpm}$ and $2^{\circ} \mathrm{C}$ for $10 \mathrm{~min}$. Pellets formed were re-suspended in $25 \mathrm{ml}$ of $50 \mathrm{mM}$ tris $\mathrm{HCl} \mathrm{pH}$ 8.5 and $2 \mathrm{mM}$ EDTA and sonicated for $30 \mathrm{sec}$, four times, with $20 \mathrm{sec}$ gap for cooling. The tube with cells was kept in crushed ice.

Supernatant was again spun in Beckmann centrifuge at $25,000 \mathrm{~g}\left(2^{\circ} \mathrm{C}\right)$ for $10 \mathrm{~min}$. Pellet formed were of membrane protein; they were re-suspended in $2 \mathrm{mM}$ Tris- $\mathrm{HCl}(\mathrm{pH} 7.8)$; and stored in a screw-capped vial in the deep freeze $\left(-20^{\circ} \mathrm{C}\right)$.

\subsubsection{Extraction of Total Protein}

$1 \mathrm{ml}$ of treated and control cultures of E. coli and $S$. aureus was added to $5 \mathrm{ml}$ of phosphate buffer and then centrifuged at $8000 \mathrm{rpm}$ for 20 mins. Supernatant was collected and extraction step was repeated 4 times. The supernatants were pooled together and the volume was made to $50 \mathrm{ml}$ with phosphate buffer.

To $1 \mathrm{ml}$ of the above extract, $1 \mathrm{ml} \mathrm{20 \%} \mathrm{Tri} \mathrm{Chloro-Acetic-}$ acid was added and after half an hour centrifuged at 8000 rpm for $20 \mathrm{~min}$. Pellet was washed twice with acetone and again centrifuged. Supernatant was discarded and the pellet was mixed in $5 \mathrm{ml}$ of $0.1 \mathrm{~N} \mathrm{NaOH}$.

\subsubsection{Gel for SDS PAGE}

$5 \%$ of Stacking gel and $10 \%$ of Resolving gel were used. SDS-PAGE was carried out using membrane and total protein samples.

\subsubsection{Protein Sample Preparation for Electrophoresis}

The sample protein was denatured in $2 \mathrm{ml}$ gel sample buffer containing $1.25 \mathrm{ml} 0.5 \mathrm{M}$ Tris- $\mathrm{HCl}(\mathrm{pH} \mathrm{6.8)}, 1 \mathrm{ml} \beta$ mercapto-ethanol, $2 \mathrm{ml}$ glycerol; $0.4 \mathrm{ml} 1 \%$ bromophenol blue to $0.4 \mathrm{~g}$ SDS and the final volume was made to $10 \mathrm{ml}$ with distilled water.

$25 \mu \mathrm{l}$ of the above mentioned protein samples were loaded 
in each well of the electrophoretic gel. GENE I Protein Molecular Weight Marker ${ }^{\mathrm{TM}}$ RPMW-H, having a range of 29$205 \mathrm{kDa}$, mol. wt. was used as standard protein.

Initially 10-15 mA current was applied for 10-15 min i.e. until the samples started traveling through the stacking gel. Then current supply was increased to $30 \mathrm{~mA}$ until the bromophenol blue dye reached near the bottom of the gel slab. The gel slab was kept in a trough containing staining solution (200 ml methanol $+35 \mathrm{ml}$ glacial acetic acid +1.25 g Coomassie Brilliant Blue R-250 made to $500 \mathrm{ml}$ by adding distilled water) until clear bands were observed. Excess stain was removed by keeping the gel in de-staining solution (75 $\mathrm{ml}$ of glacial acetic acid $+50 \mathrm{ml}$ of methanol final volume made to 1 liter. with distilled water).

\subsection{Biochemical assay of total cellular protein [6], of microbes treated with MWCNT and light}

\subsubsection{Protein Estimation}

To $1 \mathrm{ml}$ aliquot of the treated and untreated microbial suspension, $5 \mathrm{ml}$ of freshly prepared alkaline copper sulphate reagent was added; after $10 \mathrm{~min} 0.5 \mathrm{ml}$ of Folin's reagent was added, mixed well and allowed the color to develop for 30 minutes. Absorbance was recorded at $660 \mathrm{~nm}$ after setting the instrument with reagent blank which contains $1 \mathrm{ml}$ $0.1 \mathrm{~N} \mathrm{NaOH}$ instead of sample aliquot. Standard curve with graded concentration of Bovine Serum Albumin was plotted.

\subsection{Free amino acid assay by Ninhydrin method [5]}

\subsubsection{Free amino acids extraction}

was done by adding $70 \%$ ethanol to the microbial suspension. Homogenate was centrifuged at $5000 \mathrm{rpm}$ for 10 min. Supernatant was decanted. This step was repeated 4 times. All supernatants were pooled together and final volume was made to $50 \mathrm{ml}$ with $70 \%$ ethanol.

\subsubsection{Sample preparation}

$10 \mathrm{ml}$ of ethanol extract was evaporated to dryness on a boiling water bath and the residue was dissolved in $5 \mathrm{ml}$ of $0.2 \mathrm{M}$ citrate buffer ( $\mathrm{pH} 5.5$ ).

\subsubsection{Free amino acid estimation}

To $2 \mathrm{ml}$ of the above sample, $1 \mathrm{ml}$ of Ninhydrin reagent was added and kept in boiling water bath for $20 \mathrm{~min}$. It was cooled and volume was made to $10 \mathrm{ml}$ with distilled water. Absorbance was recorded at $570 \mathrm{~nm}$ using $0.2 \mathrm{M}$ citrate buffer $\mathrm{pH} 5.5$ as blank. Simultaneously a standard curve using graded concentrations of glycine $(0-100 \mu \mathrm{g})$ was plotted.

\subsection{Morphological Characterization, of E. coli and S.} aureus treated with MWCNT and sunlight by SEM

Treated and control samples of microbes were dehydrated in acetone and the SEM micrographs were taken in a CoJoel (SEM-3010).

\section{Results and Discussion}

\subsection{Percentage Survival/Mortality of E. coli and S. aureus exposed to MWCNT and sunlight}

Survival of E. coli and S. aureus cells after 30 minutes of exposure to different concentrations $(10,100,500 \mathrm{mg} / \mathrm{l})$ of MWCNT and sunlight was recorded by Colony Count (Table 1 and 2). It must be mentioned here that during growth cycle microbes do perish due to natural death, hence those microbes which were not exposed to MWCNT (Control) also exhibited some mortality. The surviving microbes in control were taken as $100 \%$ survival and the rest of the mortality/survival was calculated after deducting them.

Tables 1 and 2 very clearly give an indication of photocatalytic activity of MWCNT that caused the mortality of $E$. coli and $S$. aureus. When both the microbes were grown in sunlight with MWCNT $(100,500 \mathrm{mg} / \mathrm{l})$ barely 1-3\% micro-

Table 1. Percentage mortality/survival of E. coli exposed to different concentrations of MWCNT for 30 minutes in dark and sunlight

\begin{tabular}{|c|c|c|c|}
\hline $\begin{array}{l}\text { Treatment given to } E \text {. coli for } \\
\qquad 30 \text { minutes }\end{array}$ & Colony Count $[\mathrm{cfu} / \mathrm{ml}]$ & $\begin{array}{l}\text { \% survival }[(\mathrm{x} / 394) \times 100] \\
\text { dilution } \mathrm{used}=10^{-3}\end{array}$ & $\%$ Mortality \\
\hline Culture (control) & $3.944 \times 10^{5}$ & 100 & 0 \\
\hline Culture + Dark & $3.94 \times 10^{5}$ & 99.98 & 0.02 \\
\hline Culture + Dark + 10 ppm CNT & $3.67 \times 10^{5}$ & 93.05 & 6.95 \\
\hline Culture + Dark + 100 ppm CNT & $3.546 \times 10^{5}$ & 89.90 & 10.1 \\
\hline Culture + Dark + 500 ppm CNT & $3.546 \times 10^{5}$ & 89.90 & 10.1 \\
\hline Culture + Sunlight & $2.784 \times 10^{5}$ & 70.58 & 29.42 \\
\hline Culture + Sunlight +10 ppm CNT & $1.471 \times 10^{5}$ & 37.29 & 62.71 \\
\hline Culture + Sunlight +100 ppm CNT & $0.127 \times 10^{5}$ & 3.22 & 96.78 \\
\hline Culture + Sunlight $+500 \mathrm{ppm} \mathrm{CNT}$ & $0.056 \times 10^{5}$ & 1.41 & 98.53 \\
\hline
\end{tabular}


Table 2. Percentage survival/mortality of $S$. aureus exposed to different concentrations of MWCNT for 30 minutes I dark and sunlight

\begin{tabular}{cccc}
\hline $\begin{array}{c}\text { Treatment given to S.aureus for } \\
30 \text { minutes }\end{array}$ & $\begin{array}{c}\text { Colony Count per ml } \\
\left.\text { (dilution used: } 10^{-3}\right)[\mathrm{cfu} / \mathrm{ml}]\end{array}$ & $\begin{array}{c}\text { \% survival }[(\mathrm{x} / 394) \times 100] \\
\text { dilution used=10 }\end{array}$ & \%ortality \\
\hline Culture (control) & $4.571 \times 10^{5}$ & 100 & 0 \\
Culture + Dark & $4.562 \times 10^{5}$ & 99.80 & 0.2 \\
Culture + Dark + 10 ppm CNT & $4.464 \times 10^{5}$ & 97.65 & 2.35 \\
Culture + Dark + 100 ppm CNT & $4.427 \times 10^{5}$ & 96.84 & 3.16 \\
Culture + Dark + 500 ppm CNT & $4.414 \times 10^{5}$ & 96.56 & 3.44 \\
Culture + Sunlight & & & 17.75 \\
Culture + Sunlight + 10 ppm CNT & $3.760 \times 10^{5}$ & 82.25 & 69.79 \\
Culture + Sunlight + 100 ppm CNT & $1.381 \times 10^{5}$ & 30.21 & 99.06 \\
Culture + Sunlight + 500 ppm CNT & $0.043 \times 10^{5}$ & 0.94 & 98.52 \\
\hline
\end{tabular}

bes could survive i.e. indicating a mortality of more than $98 \%$. It was interesting to note that photocatalytic damaging effect of MWCNT and sunlight was almost the same for both $E$. coli and $S$. aureus (Table 1,2) i.e. within $30 \mathrm{~min}$ of exposure, maximum mortality occurred. So far as the impact of concentration of MWCNT with which microbes were treated i.e. $10,100,500 \mathrm{mg} / \mathrm{l}$, is concerned all the three concentrations were fatal. With the increase in concentration, the mortality increased for both the tested microbes.

The SEM micrographs presented in the Fig. 1 and 2 show disintegrated cells and ruptured cell membranes of the microbes treated with MWCNT and visible light. Hence it can be concluded that the mortality was due to the rupture of cell membrane of microbes.
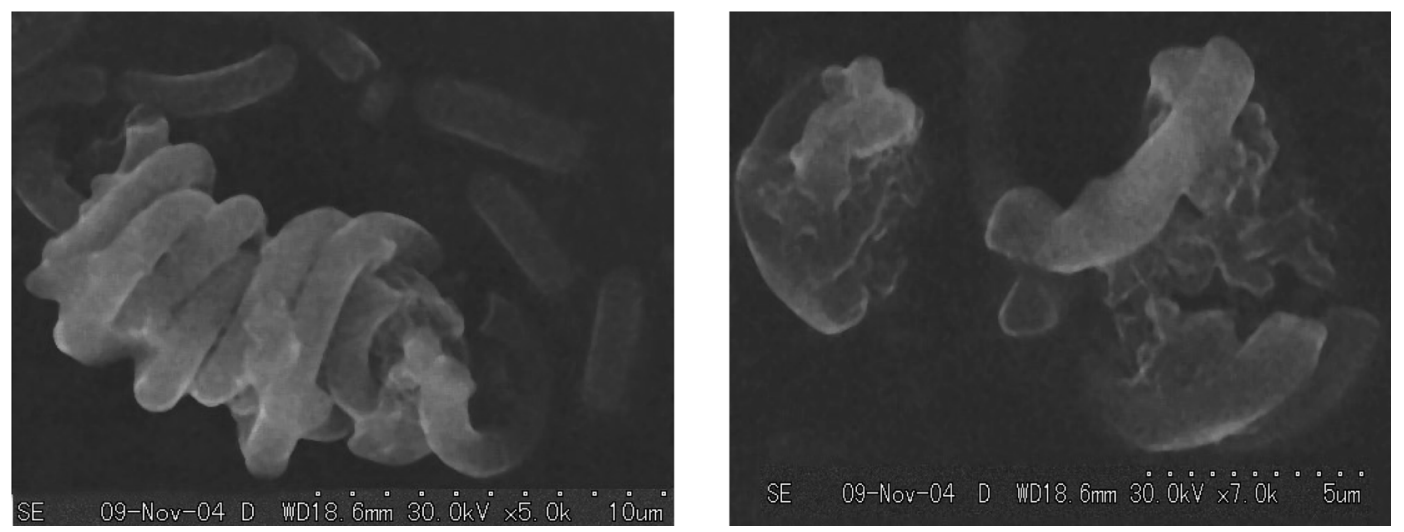

Fig. 1. Scanning Electron Micrographs of E. coli treated with $100 \mathrm{ppm}$ of MWCNT and Sunlight; showing ruptured cell membranes as well as some disintegrated cells of $E$. coli.
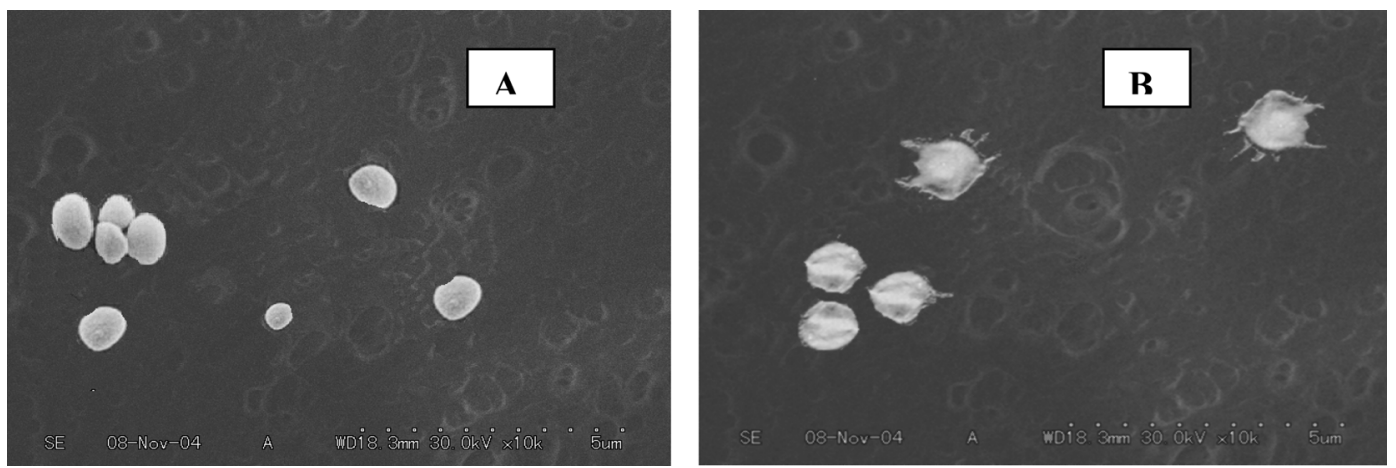

Fig. 2. Scanning Electron Micrographs of $S$. aureus treated with 100 ppm of MWCNT and Sunlight showing (A) healthy cells and (B) cells with ruptured cell membrane. 
E.coli membrane protein

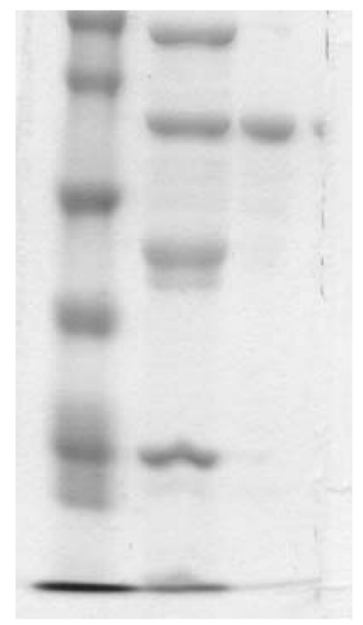

$\begin{array}{lll}\text { M } & \text { C }\end{array}$
S.aureus membrane protein

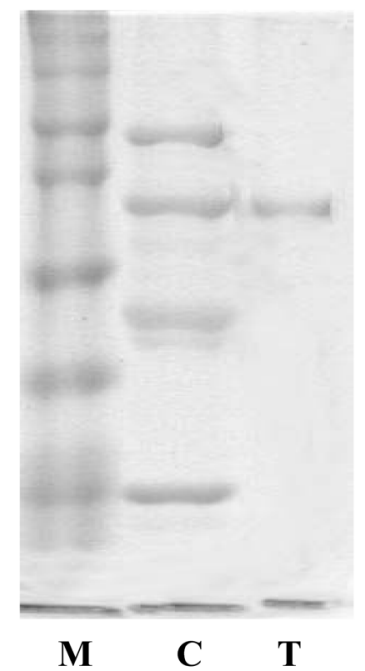

Fig. 3. SDS-PAGE of membrane proteins of E. coli and $S$. aureus treated with $100 \mathrm{mg} / \mathrm{l} \mathrm{MWCNT}$ in dark (C), light (T) and Marker Protein $(\mathrm{M})$. ( $\mathrm{T}$ of both the microbes is showing only one band of membrane protein a compared to five bands of membrane protein of control, after denaturation due to photocatalytic activity of MWCNT).

\subsection{Membrane and Cellular protein}

It was decided to study whether membrane rupture as can be seen in Fig. 1 and 2 was due to photocatalytic degradation of membrane and total cellular proteins or not.

Gel Electrophoresis analysis of membrane protein very clearly (Fig. 3) shows that when microbes were treated with MWCNT and light, only one clear protein band was observed in both the microbes. Whereas untreated E. coli had 6 and $S$. aureus had 8 protein bands.

Absence of 2 protein bands in SDS PAGE of E. coli and 3 in $S$. aureus was also noted when total cellular protein was analyzed. Thus confirming the theory that MWCNTs can photocatalytically degrade the proteins (Fig. 4).

\subsection{Biochemical analysis of total protein}

Table 3 also indicated reduction in protein content when
E.coli total protein

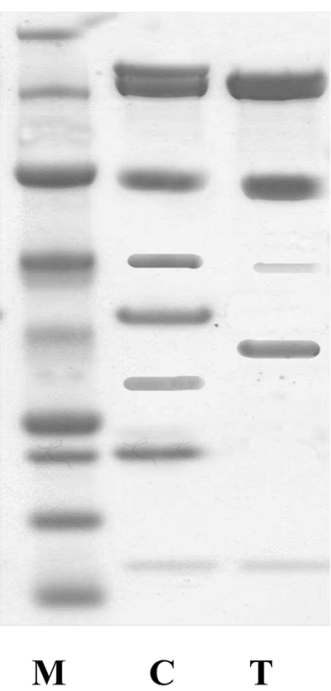

S.aureus total protein

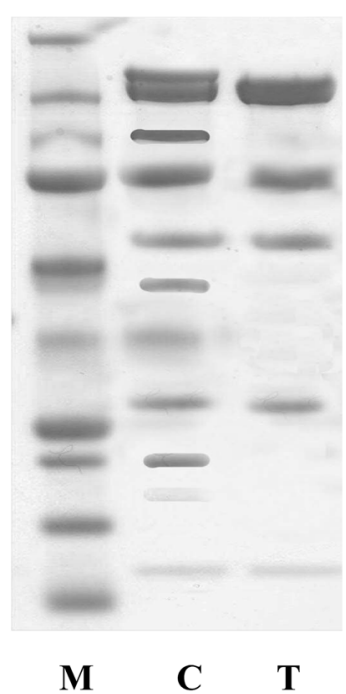

Fig. 4. SDS-PAGE of Total cellular proteins of E. coli and $S$. aureus treated with $100 \mathrm{mg} / \mathrm{l} \mathrm{MWCNT}$ in dark (C) and light (T) and Marker Protein (M). ( $\mathrm{T}$ of E. coli is showing only four bands of proteins as compared to eight bands in control and $\mathrm{T}$ of $S$. aureus is showing only four clear bands of proteins as compared to ten bands in control; after denaturation due to photocatalytic activity of MWCNT).

microbes were treated with MWCNT and light. The reduction in total protein content was more in $S$. aureus i.e. approximately $80 \%$, where as it was about $70 \%$ in E. coli. The percentage is as compared to initial protein content. May be that is why only $1 \% \mathrm{~S}$. aureus could survive (i.e. 99\% mortality) when exposed to $500 \mathrm{mg} / \mathrm{l}$ MWCNT. Survival of E. coli $2 \%$ for the same treatment. Suggesting that microbial death is due to photocatalytic degradation of membrane as well as total cellular protein.

\subsection{Free amino acids}

There are two major types of bacteria: Gram-positive and Gram-negative. The cell wall of Gram-positive bacteria consists of many polymer layers of Peptidoglycan connected by amino acid bridges. The Peptidoglycan polymer is composed of an alternating sequence of $\mathrm{N}$-acetylglucosamine

Table 3. Total protein content in E. coli and S. aureus cells before and after the treatment with different concentrations of MWCNT and sunlight (20 K Lux)

\begin{tabular}{|c|c|c|c|c|}
\hline \multirow[t]{2}{*}{ SAMPLE } & \multicolumn{4}{|c|}{$\begin{array}{l}\text { EFFECT OF CNT ON TOTAL PROTEIN CONTENT }(\mu \mathrm{g} / \mathrm{ml}) \\
\text { IN MICROBES TREATED FOR } 30 \text { MINUTES }\end{array}$} \\
\hline & Control & $10 \mathrm{mg} / \mathrm{l} \mathrm{CNT}$ & $100 \mathrm{mg} / \mathrm{l} \mathrm{CNT}$ & $500 \mathrm{mg} / \mathrm{l} \mathrm{CNT}$ \\
\hline E. coli + Dark & $233 \mu \mathrm{g} / \mathrm{ml}$ & $231 \mu \mathrm{g} / \mathrm{ml}$ & $230 \mu \mathrm{g} / \mathrm{ml}$ & $229 \mu \mathrm{g} / \mathrm{ml}$ \\
\hline E. coli + Sunlight & $235 \mu \mathrm{g} / \mathrm{ml}$ & $150 \mu \mathrm{g} / \mathrm{ml}$ & $87 \mu \mathrm{g} / \mathrm{ml}$ & $72 \mu \mathrm{g} / \mathrm{ml}$ \\
\hline S. aureus + Dark & $283 \mu \mathrm{g} / \mathrm{ml}$ & $280 \mu \mathrm{g} / \mathrm{ml}$ & $278 \mu \mathrm{g} / \mathrm{ml}$ & $277 \mu \mathrm{g} / \mathrm{ml}$ \\
\hline S. aureus + Sunlight & $285 \mu \mathrm{g} / \mathrm{ml}$ & $139 \mu \mathrm{g} / \mathrm{ml}$ & $83 \mu \mathrm{g} / \mathrm{ml}$ & $58 \mu \mathrm{g} / \mathrm{ml}$ \\
\hline
\end{tabular}


Table 4. Free Amino Acids content in E. coli and S. Aureus cells with and without the treatment with different concentrations of MWCNT and sunlight

\begin{tabular}{lcccc}
\hline & \multicolumn{3}{c}{ EFFECT OF CNT ON FREE AMINO } \\
& \multicolumn{3}{c}{ ACIDS $(\mu \mathrm{g} / \mathrm{ml})$ IN MICROBES } \\
\cline { 2 - 5 } SAMPLE & Control & $10 \mathrm{ppm}$ & 100 ppm & 500 ppm \\
& & CNT & CNT & CNT \\
\hline E. coli + Dark & 19 & 43 & 43 & 47 \\
E. coli + Sunlight & 16 & 102 & 132 & 151 \\
S. aureus + Dark & 42 & 45 & 48 & 57 \\
S. aureus + Sunlight & 40 & 122 & 131 & 148 \\
\hline
\end{tabular}

and $\mathrm{N}$-acetyl-muraminic acid. Each Peptidoglycan layer is connected, or cross-linked, to the other by a bridge made of amino acids and amino acid derivatives. The cell wall of Gram-negative bacteria is much thinner, being comprised of only $20 \%$ Peptidoglycan.

An increased level of free amino acids (Table 4) in the treated microbes may be from the damaged wall structure i.e. freeing the amino acids from 'amino acid bridge' of peptide glycan or it may be due to breaking down of protein molecules of membrane or cellular protein.

In vitro action of carboxy- fullerene has been demonstrated by Teo et al. [7]. Fullerene compounds have avid reactivity with free radicals and are regarded as 'radical sponges'. And has been shown to be effective in the treatment of both Gram-positive and gram-negative infection ${ }^{\text {s }}$, although its mode of action is poorly understood. However, they also envisaged that destruction of membrane integrity must have been the cause of bacterial death.

The above observation of mortality of microbes grown in presence of MWCNT and light confirm that photocatalytic activity of MWCNT and confirms that any organic material or water, present near the interface of semiconducting particles (MWCNT), would get quickly oxidized [8]. The chances are that proteins having disulfide groups are likely to be the ones that might have got affected by photocatalytic activity of MWCNT.

\section{Photocatalytic Process of killing bacteria}

Whenever a semiconductor material (in present study, semiconducting carbon with band gap $1.2 \mathrm{eV}$ ) comes in contact with another material of Fermi energy different to semiconductor, a depletion region is formed. This depletion region on exposure to band gap light, electron from valence and of the semiconductor gets excited to conduction band creating one electron/hole pair per photon absorbed. These electron/hole pairs have natural tendency to annihilate, but due to formation of depletion region, instead of getting annihilated are forced to react with materials in contact with the semiconductor $[9,10]$. Since water is in far excess, water reacts with these electron/hole pairs producing hydroxyl radicals, which are also very reactive. These hydroxyl radicals or electron photo-generated electron/hole pairs tend to react with any other organic materials present in their vicinity, causing oxidation (due to interaction with holes) or reduction (due to interaction with electron) [11-14].

Reaction sequence is given here:

$$
\begin{aligned}
& \mathrm{CNT}+\text { light } \rightarrow \mathrm{e}^{-}+\mathrm{h}^{+} \\
& \mathrm{h}^{+}+\mathrm{H}_{2} \mathrm{O} \rightarrow \mathrm{OH}^{*}+\mathrm{H}^{+} \\
& \mathrm{O}_{2}+\mathrm{e}^{-} \rightarrow \mathrm{O}_{2}{ }^{*-} \\
& \text { Protein (cell membrane) }+\mathrm{OH}^{*}\left(\text { or }^{+}\right) \rightarrow \mathrm{CO}_{2}+\mathrm{H}_{2} \mathrm{O} \\
& \quad+\text { remaining oxidized product }
\end{aligned}
$$

Thus when the membrane of the cell comes in contact with either hydroxyl radicals or photo-generated holes, its protein would either get completely oxidized to carbon dioxide or it may get partly denatured releasing amino acids due to break in peptide bonds in a protein [7-9].

In the present experiment, SDS PAGE analysis has shown that when bacterial cells were exposed to Sun and MWCNT, the number of protein bands became less as compared to control. Absence of protein bands prove that protein component of the cell membrane as well as cell both got denatured by photocatalytic activity.

\section{Conclusion}

In presence of sun-light, semiconducting carbon (MWCNT) with a band gap of $1.2 \mathrm{eV}$ can kill $E$. coli and $S$. aureus. It is proposed that the killing is due to photocatalytic denaturation of membrane as well as cell protein.

\section{Acknowledgements}

Authors wish to acknowledge authorities of Nagoya Institute of Technology, Japan for providing technical support and Birla College, Kalyan, India specially Dr. Naresh Chandra, Principal for his support. We are also grateful to Monad Nanotech for providing Carbon Nanotubes and financial support at many stages of this work.

\section{References}

[1] Kroto, H. W.; Heath, J. R.; O’Brien, S. C.; Curl, R. F.; Smalley, R. E. Nature 1985, 318, 162.

[2] Sharon, M.; Pal, B.; Kamat, D. V. J. Biomed. Technol. 2005, $1,365$.

[3] Kim, J. S. Nanomedicine: Nanotechnology, Biology \& Medicine 2007, 3, 95.

[4] Yoon, Y. Science of the Total Environment 2007, 373, 572.

[5] Walker, I. M. The Protein Protocol Handbook 1996, 
Humana press, Totowa, NJ.

[6] Sawhney, S. K., Singh, R. "Introductory Practical Biochemistry", Narosa Publisher, India, 2002.

[7] Teo, K. B. K.; Lee, S. B.; Chhowalla, M.; Semet, V.; Binh, V. T.; Groening, O.; Castignolles, M.; Loiseau, A.; Pirio, G.; Legagneux, P.; Pribat, D.; Hasko, D. G.; Ahmed, H.; Amaratunga, G. A. J.; Milne, W. I. Nanotechnology 2003, 14, 204.

[8] Gupta, A.; Shah, S.; Sharon Madhuri "Nano Forms of Carbon \& Its application" ed. Mahesh war Sharon, Madhuri Sharon, Monad Nanotech Pvt. Ltd., India, 2007,
280.

[9] Sharon, M.; Pal, B. Bull Electro Chemistry 1996, 12, 219.

[10] Schiavello, M. Basic Concepts in Photocatalysis, NATO ASI Ser., Ser.C, 1988, 233, 351.

[11] Pal, B.; Sharon, M. Materials Chemistry and Physics, 2002, 59, 254.

[12] Pal, B.; Sharon, M.; Nogami, G. Materials Chemistry \& Physics 1999, 59, 254.

[13] Pal, B.; Sharon, M. J. Molecular Catalysis A: Chemical 2000, 160, 453.

[14] Pal, B.; Sharon, M. Thin Solid Films 2000, 379, 83. 